\title{
Pengembangan Perangkat Pembelajaran Biologi Berbasis Pendekatan Saintifik Model Guided Discovery Untuk Siswa SMA
}

\author{
Raden Sumiadi \\ Dosen PGSD STKIP Hamzar \\ Email: radensumiadi01@gmail.com
}

\begin{abstract}
Abstrak; Penelitian ini bertujuan untuk: 1) Mengembangkan perangkat pembelajaran berbasis pendekatan saintifik dengan model guided discovery, 2) mengetahui kelayakan perangkat pembelajaran berbasis pendekatan saintifik model guided discovery. Pengembangan perangkat pembelajaran menggunakan model 4D dari Tiahgrajan, S. Semmel \& Semmel yang dimodifikasi menjadi tiga tahap, yaitu tahap define, design, dan development. Hasil pengembangan perangkat pembelajaran selanjutnya dianalisis menggunakan rumus presentase rata-rata yang disesuaikan dengan Tabel kriteria hasil validasi, perangkat pembelajaran berbasis pendekatan saintifik model guided discovery dikategorikan baik dan sangat baik dengan nilai rata-rata silabus $(3,5), \mathrm{RPP}(3,5)$, LKDS $(3,6)$, BAS $(3,6)$, TPK dan TBK $(3,8)$ sehingga layak digunakan dalam proses pembelajaran biologi di SMAN.
\end{abstract}

\section{Kata Kunci: Perangkat Pembelajaran, Pendekatan Saintifik, Guided Discovery}

\section{PENDAHULUAN}

Tujuan makro pendidikan nasional adalah membentuk manusia yang beriman dan bertaqwa kepada Tuhan Yang Maha Esa, beretika, memiliki nalar, berkemampuan komunikasi sosial, dan berbadan sehat sehingga menjadi manusia mandiri (Mulyasa, 2004). Untuk mencapai tujuan tersebut, berbagai kebijakan telah dikeluarkan oleh pemerintah diantaranya; perbaikan sarana dan prasarana pendidikan, program sertifikasi guru, dan perubahan kurikulum. Namun demikian, upaya tersebut belum menunjukkan hasil yang memuaskan. Jika merujuk pada data kualitas pendidikan Indonesia yang dirilis oleh Programme for International Student Assessment (PISA) Tahun 2000, 2003, 2006 (Hadi et al. 2009), 2009 dan 2012 ternyata kemampuan literasi sains anak Indonesia masih rendah (Pratiwi, 2014).

Rendahnya kemampuan literasi sains siswa berkaitan erat dengan lemahnya proses pembelajaran IPA di kelas. Hal tersebut disebabkan karena belum memadainya kemampuan guru dalam mengembangkan perangkat pembelajaran yang berbasis kepada siwa belajar aktif. Guru lebih cenderung menggunakan perangkat pembelajaran hasil download internet. Disisi lain, guru memiliki peranan yang sangat penting dalam mengembangkan kemampuan berpikir siswa sehingga, guru dituntut untuk dapat mengembangkan perangkat pembelajaran yang berorientasi pada siswa belajar aktif baik mengamati, menanya, mengumpulkan data, mengasosiasi, dan mempublikasi.

Pendekatan saintifik merupakan pembelajaran yang substansinya dapat membimbing siswa sebagai subyek belajar yang aktif melalui kegiatan ilmiah untuk membangun konsep, hukum, dan prinsip melalui tahap mengamati, menanya, mengumpulkan data, menalar, dan mengkomunikasikan data. Sawitri (2014) mengungkapkan, proses pembelajaran menggunakan pendekatan saintifik dapat meningkatkan hasil belajar siswa SMA. Sejalan dengan itu, Machin (2014) mengemukakan bahwa penerapan pendekatan saintifik berpengaruh positif terhadap hasil belajar kognitif siswa SMA. Namun demikian, pendekatan saintifik masih bersifat umum jika digunakan dalam mengelola pembelajaran di kelas, oleh karena itu dibutuhkan model pembelajaran yang tepat untuk memperkuat pendekatan pembelajaran tersebut. Salah satunya adalah model pembelajaran guided discovery.

$$
\text { Guided discovery merupakan }
$$
pembelajaran yang mengikuti pola kerja ilmiah yang dapat digunakan untuk membangun konsep di bawah bimbingan guru sehingga guru lebih kreatif dalam menciptakan situasi yang dapat membuat 
siswa belajar aktif menemukan pengetahuan sendiri (Sani, 2014). Model pembelajaran Guided discovery menekankan kreativitas belajar, siswa didorong untuk berpikir dan menganalisis sendiri sehingga dapat menemukan konsep berdasarkan data yang disediakan melalui kegiatan eksperimen dan eksplorasi buku. Rahmawati et al. (2014) dalam penelitiannya mengungkapkan bahwa pembelajaran menggunakan model guided discovery dapat meningkatkan hasil belajar siswa. Sejalan dengan itu, Afian (2014) mengemukakan bahwa proses pembelajaran dengan menggunakan model guided discovery dapat mengefektifkan penguasaan konsep biologi dan kemampuan berpikir kreatif siswa. Merujuk pada hasil penelitian tersebut, sehingga perlu dikembangkan perangkat pembelajaran berbasis pendekatan saintifik model guided discovery.

\section{METODE}

Penelitian ini merupakan jenis penelitian pengembangan yang dikembangkan dengan model 4D yang meliputi 4 tahapan yaitu, tahap define yaitu tahap analsis masalah, analisis siswa, analisis tugas, analisis konsep, dan spesifikasi tujuan pembelajaran. Tahap design yaitu penyusunan tes, pemilihan media, pemilihan format. Tujuan pada tahap ini adalah menyiapkan perangkat pembelajaran dan penyusunan tes sebagai penghubung antara design dan tahap define. Tahap develop yaitu tahap perangkat pembelajaran divalidasi oleh tim ahli pendidikan. Tahap desseminate tidak dilakukan daslam penelitian karena keterbatasan waktu.

Perangkat pembelajaran yang dikembangkan dalam penelitian ini berupa rencana pelaksanaan pembelajaran (RPP), lembar kegiatan discovery siswa (LKDS), Buku Ajar siswa (BAS), tes penguasaan konsep (TPK), dan tes berfikir kreatif (TBK). Perangkat pembelajaran disusun dengan pendekatan saintifik model guided discovery.

\section{HASIL DAN PEMBAHASAN}

Penelitian dan pengembangan (R\&D) perangkat pembelajaran biologi berbasis pendekatan saintifik dengan model guided discovery terdiri dari dua tahap, yaitu tahap pengembangan dan tahap uji coba kelompok terbatas. Untuk memperoleh data, perangkat pembelajaran yang telah dikembangkan selanjutnya divalidasi oleh ahli pendidikan biologi dan diuji coba kelompok terbatas pada siswa SMA. Hasil pengembangan dan uji coba tersebut dapat dideskripsikan sebagai berikut:

Tabel.1 Skor validasi ahli

\begin{tabular}{|l|l|l|l|}
\hline No & Perangkat & Nilai & Kategori \\
\hline 1 & SILABUS & 3,5 & Baik \\
\hline 2 & RPP & 3,5 & Baik \\
\hline 3 & LKDS & 3,6 & Sangat baik \\
\hline 4 & BAS & 3,6 & Sangat baik \\
\hline 5 & TPK dan TBK & 3,8 & Sangat baik \\
\hline
\end{tabular}

Perangkat pembelajaran yang dikembangkan dalam penelitian ini disesuaikan dengan tuntutan kurikulum 2013 yaitu menggunakan pendekatan saintifik model pembelajaran guided discovery. Karakteristik perangkat tersebut yaitu; dikembangkan dengan pendekatan saintifik model guided discovery, kegiatan pembelajaran menekankan pada aktivitas siswa dalam membangun konsep, dan berupaya membimbing siswa melakukan kegiatan mengamati, merumuskan masalah, mengumpulkan data, mengolah data, dan mengkomunikasikan data. Perangkat pembelajaran yang telah dikembangkan selanjutnya di validasi oleh tiga orang validator di bidang pendidikan.

Berdasarkan nilai validasi ahli terhadap perangkat pembelajaran yang telah dikembangkan, diperoleh nilai rata-rata kategori baik (valid) dan sangat baik (sangat valid) dengan sedikit revisi. Silabus $(3,5)$, RPP $(3,5)$, LKDS $(3,6)$, BAS $(3,6)$, TPK dan TBK $(3,8)$. Berdasarkan hal itu, perangkat pembelajaran yang dikembangkan peneliti layak dan dapat digunakan dalam proses pembelajaran di SMA. Hal ini sejalan dengan penelitian Putrawan et al. (2014) bahwa hasil pengembangan perangkat pembelajaran diperoleh kategori baik, layak, dan efektif. Afian (2014) bahwa perangkat pembelajaran model guided discovery berkategori baik, layak, dan efektif digunakan dalam mengelola pembelajaran biologi di kelas. Rahmawati et al. (2014) perangkat pembelajaran berbasis penemuan terbimbing dikategorikan valid 


\section{KESIMPULAN}

Berdasarkan hasil pembhasan di atas dapt disimpulkan bahwa perangkat pembelajaran berbasis pendekatan saintifik model guided discovery dikategorikan baik dan sangat baik sehingga layak digunakan dalam proses pembelajaran di SMA.

\section{DAFTAR PUSTAKA}

Afian, T. 2014. Pengembangan Perangkat Pembelajaran Sains Berorientasi Guided Discovery Untuk Mengajarkan Kemampuan Berpikir Kreatif dan Penguasaan Konsep. Tesis: Universitas Negeri Surabaya.

Afifah, R., Rusilowati, A dan Supriyadi. 2014. Keefektifan Model Pembelajaran Guided Discovery dengan Media Question Cardas Bervisi SETS dalam Membelajarkan Kebencanaan Alam Terintegrasi dalam IPA. Unnes Physic Education Journal. Volume 3. No 1. Halaman 1: Diunduh dari http://journal. unnes.ac.id/sju/index phpupej Tanggal 4 Januari 2015.

Akbar, S. 2013. Instrumen Perangkat Pembelajaran.

Rosdakarya

Anggraeni, D. 2013. Pengembangan Buku Panduan Pembelajaran Berbasis Model Siklus Belajar untuk Mengoptimalkan Proses dan Hasil Belajar Siswa SMA/ MA. Tesis: Universitas Mataram.

Badan Pengembangan Sumber Daya Manusia Pendidikan dan Kebudayaan dan Penjamin Mutu Pendidikan. 2014. Materi Pelatihan Guru Implementasi Kurikulum 2013 Tahun Ajaran 2014/2015 Mata Pelajaran IPA. Jakarta: Kementrian Pendidikan dan Kebudayaan.

Citrawathi, M.D \& Adnyana, B.P. 2008. Pengembangan Modul Biologi Berorientasi Siklus Belajar untuk Meningkatkan Penalaran dan Keterampilan Inkuiri Siswa SMA. Jurnal Penelitian dan Pengembangan Pendidikan. Volume 2. No 3. Halaman 207: Diunduh dari http://www.lemlit-undiksha.co.nr Tanggal 4 Januari 2015.

Depdiknas. 2003. Standar Kompetensi Mata Pelajaran Biologi SMA dan MA. Jakarta: Pusat Kurikulum Balitbang Depdiknas.
Machin, A. 2014. Implementasi Pendekatan Saintifik, Penanaman Karakter dan Konservasi pada Pembelajaran Materi Pertumbuhan. Jurnal Pendidikan IPA Indonesia. Volume 3. No 1. Halaman di unduh dari http://journal.unnes.ac.id/nju/index.php/jpii Tanggal 8 Januari 2015.

Mursali, S. 2013, Pengembangan Perangkat Pembelajaran Biologi SMA Berbasis Metakognitif untuk Meningkatkan Kemampuan Kognitif dan Mengembangkan Perilaku Berkarakter Siswa. Tesis: Universitas Negeri Surabaya.

Permendikbud. 2014. Standar proses pendidikan. Jakarta: Kementrian Pendidikan dan Kebudayaan

Prastowo, A .2014. b. Pengmbangan Bahan Ajar Tematik Tinjauan Teoritis dan Praktik. Jakarta: Kencana Prenada Media Group.

Prasetyo, K.Z. 2011. Pengembangan Perangkat Pembelajaran Sains Terpadu Untuk Meningkatkan Kognitif, Keterampilan proses, Kreativitas serta Menerapkan Konsep Ilmiah Peserta Didik SMP. Laporan Penelitian: UNY.

Pratiwi, A.F. 2014. Pengaruh Penggunaan Model Discovery Learning dengan Pendekatan Saintifik Terhadap Keterampilan Berpikir Kritis Siswa SMA. Diunduh dari http://www.ejournal.ac.id.unesa/article, diakses tanggal 7 Januari 2015.

Pratiwi. 2006. Biologi SMA. Jakarta: Erlangga.

Putrawan, P.A., Suharta, P.G dan Sariyasa. 2014. Pengembangan Perangkat Pembelajaran Matematika Dengan Pendekatan Scientific Berbantuan Geogebra Dalam Upaya Meningkatkan Keterampilan Komunikasi Dan Aktivitas Belajar Matematika Siswa Kelas VIII SMP. e-Journal Program Pascasarjana Universitas Pendidikan Ganesha. Volume 3. No 1. Halaman 21-26: Diunduh dari http://www pasca.ganesha.id Tanggal 7 Januari 2014.

Rahmawati, Y., Mardiana, dan Subanti, S. 2014. Pengembangan Perangkat Pembelajaran Berbasis Penemuan Terbimbing (guided discovery) dengan 
Pendekatan Somatic, Auditory, Visual, Intellectual (savi) pada Materi Pokok Peluang Kelas IX SMP. Jurnal Elektronik Pembelajaran Matematika: Volume 2. No 4. Halaaman 379-388: Diunduh dari http://journal.fkip.uns.ac.id tanggal 7 Januari 2015.

Sagala, S. 2013. Konsep dan Makna Pembelajaran Untuk Membantu Memecahkan problematika Belajar dan Mengajar. Bandung: Alfabeta.

Sani, A.R. 2014. Pembelajaran Saintifik untuk Implementasi Kurikulum 2013. Jakarta: PT Bumi Aksara.

Satyawati, B.S.N.N. 2012. Pengaruh Model Pembelajaran Penemuan Terbimbing Berbasis LKS Terhadap Hasil Belajar Metematika Siswa ditinjau dari Kecerdasan Logis Matematis Pada Siswa Kelas X SMA N 1 Bangli. Diunduh dari http://www pasca.undiksha.ac.id/247 Tanggal 7 Januari 2015.

Sugiono, 2007. Metode Penelitian Kuantitatif, Kualitatif dan $R \& D$. Bandung: Alfabeta. 